\title{
Agroecological Practices and Agrobiodiversity: A Case Study on Organic Orange in Southern Italy
}

\author{
Corrado Ciaccia ${ }^{1, * \mathbb{C}}$, Anna La Torre ${ }^{2}$, Filippo Ferlito ${ }^{3}$, Elena Testani ${ }^{1}$, Valerio Battaglia ${ }^{2}$, \\ Luca Salvati ${ }^{4}$ and Giancarlo Roccuzzo ${ }^{5}$ (D) \\ 1 CREA-Research Centre for Agriculture and Environment, Via della Navicella 2-4, 00184 Rome, Italy; \\ elena.testani@crea.gov.it \\ 2 CREA-Research Centre for Plant Protection and Certification, Via C.G. Bertero 22, 00156 Rome, Italy; \\ anna.latorre@crea.gov.it (A.L.T.); valerio.battaglia@crea.gov.it (V.B.) \\ 3 CREA-Research Centre for Olive, Citrus and Tree Fruit, Corso Savoia 190, 95024 Acireale, Italy; \\ filippo.ferlito@crea.gov.it \\ 4 CREA-Research Center for Forestry and Woods, Viale Santa Margherita 80, 52100 Arezzo, Italy; \\ luca.salvati@crea.gov.it \\ 5 CREA-Research Centre for Olive, Citrus and Tree Fruit, via la Canapona 1 bis, 47121 Forlì, Italy; \\ giancarlo.roccuzzo@crea.gov.it \\ * Correspondence: corrado.ciaccia@crea.gov.it; Tel.: +39-06-700-54-13
}

Received: 27 December 2018; Accepted: 11 February 2019; Published: 14 February 2019

\begin{abstract}
The integration of Agroecological Service Crops (ASCs) into agroecosystems can provide several ecological services, such as nutrient cycling and disease and weed management. A two-year experiment on an organic orchard was carried out to compare barley (B) and horse bean (HB) ASCs with a control without ASC (Cont) in combination with fertilizers. Their effects on soil fertility and weed- and soil-borne fungi communities were evaluated by direct measurements, visual estimation, and indicators computation. A Principal Component Analysis (PCA) was used to identify latent patterns and redundancy among variables, whereas a correlation analysis was used to discriminate the compared systems within the PCA matrix. The empirical results of this study put in evidence the correlation among soil, weed, and fungal variables. A slight contribution of fertilizers on the system's variability was observed, whereas a clear effect of ASCs was highlighted. The systems differed in weed communities, with the lowest density associated to B and the highest to Cont. B showed the highest fungal diversity, with changes in community compared to HB. HB showed a contribution on soil fertility, being associated to organic matter increase and $\mathrm{N}$ availability, and evidencing mixed impacts on soil quality and ecosystem functioning. Overall, the above-ground diversity and below-ground community results were inter-correlated.
\end{abstract}

Keywords: cover crop; species richness; ecology of interaction; multivariate statistics

\section{Introduction}

According to the most recent projections, world population will reach 9.1 billion in 2050, corresponding to an increase of 2.2 billion people over the next 40 years [1]. Future population growth will open the discussion on how agriculture can ensure food security and environmental sustainability, reducing pollution and greenhouse emissions from the food system. Organic agriculture, in compliance with its principles of Fairness, Care, Health, and Ecology [2], takes part of this challenge. In order to reach a key role towards 2050 sustainable agricultural systems, organic agriculture needs further development based on scientific evidence in the definition of the so-called Organic 3.0 practices [3]. In this framework, Agroecology can represent a way to address Organic agriculture away from the globally standardized and business-oriented approach, which has turned the original holistic vision 
of organic farming pioneers to a more "conventionalized" input-substitution approach $[4,5]$. In fact, agroecology aims at redesigning the entire food system, encompassing the ecological, economic, and social dimensions of sustainability [6], through transdisciplinary, participatory, and change-oriented research and action [7]. Agroecology aims to build up the strength of natural ecosystems within the agroecosystems, exploiting the appropriate ecological processes and the related ecosystem services [8]. In this regard, agroecological practices can be divided into distinct measures with variable targets, including (i) efficiency increase and substitution practices and (ii) redesign practices [9]. To the first set are referred practices aimed to (a) reduce input consumption (i.e., precision farming), (b) substitute off-farm with on-farm inputs (e.g., compost production and use), and (c) improve crop productivity (e.g., microbial inoculants use). Redesign practices include diversification strategies by increasing the crop diversity in rotation, exploiting the natural biodiversity in space and time, and connecting farms with natural environments (i.e., ecological infrastructures). The links between biodiversity and ecosystem functions, services, and resilience are indeed well known [10], highlighting that appropriate management can reduce the 'disservices' or even generate services provided by agriculture [11]. As a matter of fact, the increase of species richness in a cropping system enlarges the chance to include species, which positively contribute to the overall ecosystem functioning (sampling effect), providing ecological services such as nutrient cycling or pest control $[12,13]$. The biodiversity and bio-control services link may than reduce the need for pesticides contributing to reduce chemical pollution, one of the main disservices of agriculture. Actually, agroecosystems can be managed in order to amplify the ecological functions and services by directly introducing new species and, consequently, modifying the associated diversity, namely soil biota and spontaneous flora [10]. The introduction of crops within agroecosystems not directly aimed at production but providing ecological services, moves in the direction of a redesign practice [9]. The so called Agroecological Service Crops (ASCs) [14] represent an important link between soil, crop, and associated diversity and can be a tool to manage the total agro-biodiversity. Several studies report the role of ASCs in providing specific ecological services, such as pest control $[15,16]$, weed control $[17,18]$, and soil fertility $[19,20]$. Conversely, there is a gap of knowledge on how land management and other environmental factors influence the community structure and the distribution of organisms that contribute to crop production at different time scales [13]. The mutual interaction among soil fungi and plants is well recognized. Generally speaking, soil fungi may affect plant communities through their roles as decomposers, parasites, and mycorrhizal mutualists [21]. At the same time, weeds may affect soil microbial communities through their secondary metabolites, enhancing or inhibiting their activity. However, very little is known about the specific interactions among these two kingdoms, particularly in field conditions.

In this research, a two-year experiment was carried out in an organically managed young orange orchard at the Research Center for Olive, Citrus, and Tree Fruit of the Council for Agricultural Research and Economics (CREA-OFA), in Palazzelli (SR), Sicily, South of Italy. The study aimed at investigating the effectiveness of substitution and redesign practices (i.e., on-farm compost and ASCs introduction) on biodiversity dynamics. The hypothesis was that the introduced agroecological practices would affect: (i) Weed community structure over time, (ii) soil fungi and oomycetes biodiversity, and (iii) the soil fertility parameters. With this aim, weed species and living fungal and oomycetes genera were determined in the tested systems, over the two experimental years. Moreover, the latent relationship between the biological community and the most important soil fertility attributes were finally examined.

\section{Materials and Methods}

\subsection{Site Description and Climatic Data}

The study was carried out between October 2013 and December 2015 in the Sicily region (Italy, latitude $37^{\circ} 17^{\prime} \mathrm{N}$, longitude $14^{\circ} 50^{\prime} \mathrm{E}$ ), in the 'Long term trial on organic Citrus' (PALAP9), within the experimental farm of the CREA, Research Center for Olive, Citrus, and Tree Fruit. The soil is 
classified as Eutric Cambisol [22], and the climate of the region is typical Mediterranean [23], with hot and dry summers. According to available meteorological data (30 years), annual mean reference rainfall is about $550 \mathrm{~mm}$, and the maximum temperature in summer during daytime often reaches $38-40^{\circ}$ Celsius (Figure 1). The two-year experiment focused on a young orange orchard: Orange trees (Citrus sinensis (L.) Osb.) cv. "Tarocco Rosso" grafted on Carrizo citrange rootstock (C. sinensis (L.) Osb. $\times$ Poncirus trifoliata (L.) Raf.) were planted in June 2012 at a spacing of 6 by $4 \mathrm{~m}$, and an area pertaining to each tree of $24 \mathrm{~m}^{2}$. The experimental layout was a criss-cross design with three randomized blocks (Figure S1). The vertical strip was assigned to the System management (S), which foresaw the introduction of ASC species: (i) Barley, Hordeum vulgare L. (B), and (ii) Horse bean, Vicia faba L. var. minor (HB), compared with (iii) control without ASC (Cont). The horizontal strip was assigned to the Fertilizer (F) and an amount corresponding to the dose of $50 \mathrm{~g} \mathrm{~N}^{-1}$ per each orange tree of the following materials was applied: (i) Commercial mineral fertilizer (Min) and (ii) on-farm citrus by-products compost compliant with EU organic regulations (Comp) [24]. $\mathrm{N}$ content of materials was $20 \%$ for Min and 2.0 for Comp, while the C:N ratio was 16.3 for Comp. The B and HB species were sown on 25th and 24th November in 2013 and 2014, respectively, and they were terminated on 15 and 16th April in 2014 and 2015, respectively.

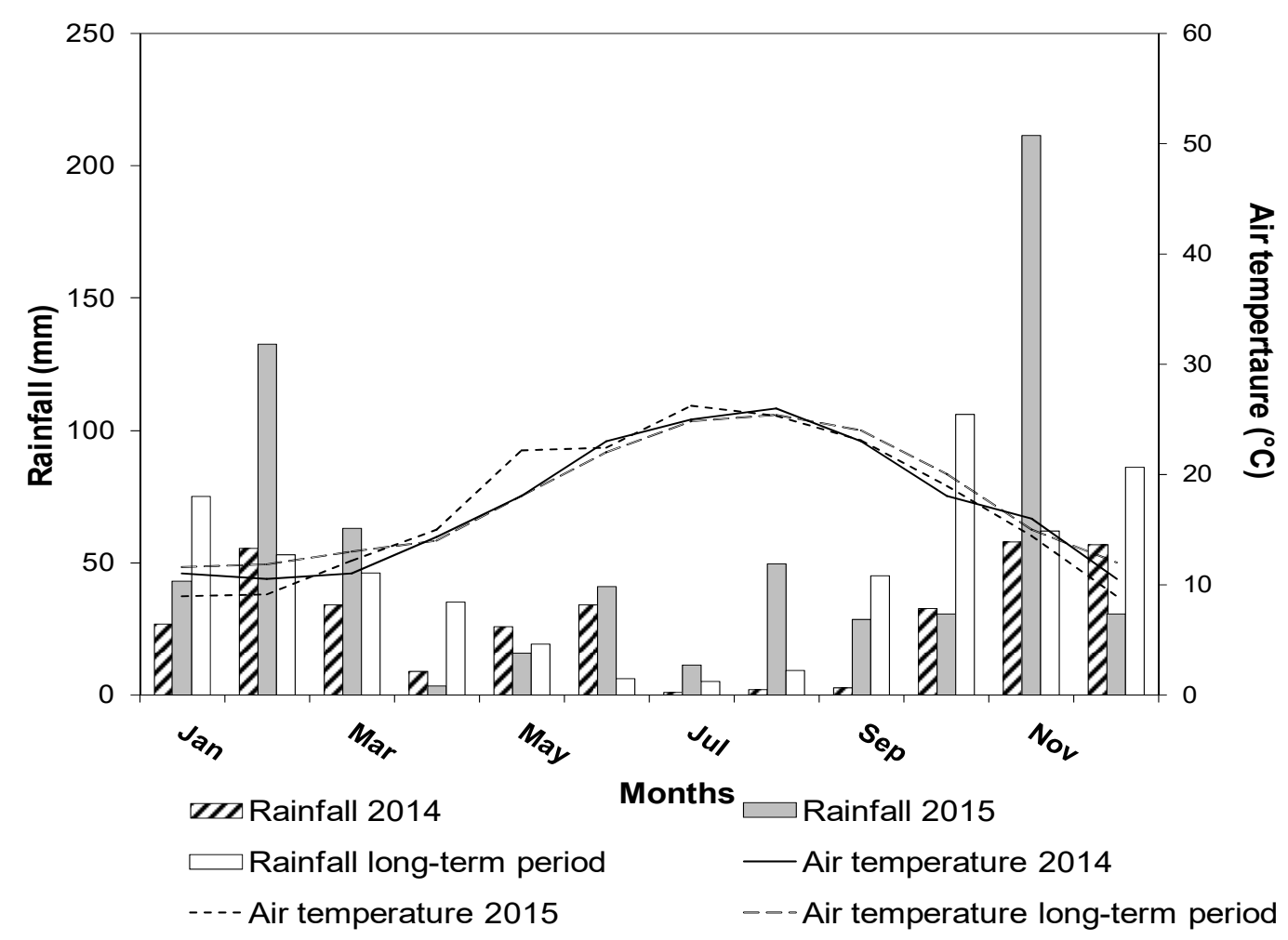

Figure 1. Mean monthly temperature and rainfall at the 'Long term trial on organic Citrus'-PALAP9 during January 2014-December 2015 compared with long-term (30 years.) mean values.

\subsection{System Management and Sampling}

The three systems were managed in a similar manner during the experimental period. Water was distributed by a drip irrigation method, and an average of $120 \mathrm{~mm}$ was supplied from May to October. Strip fertilization was carried out every year in spring.

The effects of $\mathrm{S}$ and $\mathrm{F}$ on soil fertility and fungal and weed biodiversity were assessed several times over the two experimental years, corresponding to different stages during ASC growth and after termination (25th February 2014 and 25th February 2015 for ASC growth effect assessment; 20th May 2014 and 25th May 2015 after ASC termination and fertilizer application; 3th July 2014 and 9th July 
during summer; 5th November 2014 and 27th October 2015 in ASC pre-sowing). The complete list of studied parameters is reported in Table 1.

Table 1. Complete list of analyzed parameters used as indicators for the Principal Component Analysis of the compared systems.

\begin{tabular}{|c|c|c|}
\hline Parameter & Unit & Assessment \\
\hline Total Nitrogen (TN) & $\%$ & \multirow{5}{*}{ Soil fertility } \\
\hline Total Organic Carbon (TOC) & $\%$ & \\
\hline Soil available $\mathrm{N}$ (Nitrate, ${\mathrm{N}-\mathrm{NO}_{3}}^{-}$) & $\mathrm{kg} \mathrm{ha}^{-1}$ & \\
\hline Soil available $\mathrm{N}$ (Ammonium, $\mathrm{N}-\mathrm{NH}_{4}{ }^{+}$) & $\mathrm{kg} \mathrm{ha}^{-1}$ & \\
\hline Available Phosphorus (Olsen, av $\mathrm{P}$ ) & $\mathrm{mg} \mathrm{kg}^{-1}$ & \\
\hline Amaranthus retroflexus L. (AMARE) & $\%$ & \multirow{21}{*}{ Weed community } \\
\hline Brassica nigra (L.) Koch (BRSNI) & $\%$ & \\
\hline Capsella borsa-pastoris (L.) Medik. (CAPBP) & $\%$ & \\
\hline Calendula arvensis L. (CLDAR) & $\%$ & \\
\hline Convolvulus arvensis L. (CONAR) & $\%$ & \\
\hline Cyperus rotondus L. (CYPRO) & $\%$ & \\
\hline Diplotaxis erucoides (L.) DC. (DIPER) & $\%$ & \\
\hline Conyza canadensis L. (ERICA) & $\%$ & \\
\hline Fumaria officinalis L. (FUMOF) & $\%$ & \\
\hline Lamium amplexicaule L. (LAMAM) & $\%$ & \\
\hline Malva sylvestris L. (MALSI) & $\%$ & \\
\hline Oxalis pes-caprae L. (OXAPC) & $\%$ & \\
\hline Portulaca oleracea L. (POROL) & $\%$ & \\
\hline S. arvensis, S. asper, S. oleraceus L. (Sonchus spp.) & $\%$ & \\
\hline Stellaria media (L.) Vill. (STEME) & $\%$ & \\
\hline Urtica urens L. (URTUR) & $\%$ & \\
\hline Broad leaves species (27 species) & $\%$ & \\
\hline Grass species (8 species) & $\%$ & \\
\hline Weed density & - & \\
\hline Weed Evenness (Weed e) & - & \\
\hline Weed Richness (Weed R) & $\mathrm{n} \mathrm{m}^{-2}$ & \\
\hline Alternaria spp. & $\%$ & \multirow{15}{*}{$\begin{array}{l}\text { Fungi and oomycetes } \\
\text { community }\end{array}$} \\
\hline Aspergillus spp. & $\%$ & \\
\hline Cladosporium spp. & $\%$ & \\
\hline Fusarium spp. & $\%$ & \\
\hline Graphyum sp. & $\%$ & \\
\hline Penicillium spp. & $\%$ & \\
\hline Phytophthora sp. & $\%$ & \\
\hline Rhizopus nigricans & $\%$ & \\
\hline Staphylotrichum sp. & $\%$ & \\
\hline Trichoderma spp. & $\%$ & \\
\hline Verticillium spp. & $\%$ & \\
\hline Others (20 genera) & $\%$ & \\
\hline Colony Forming Unit (Ln-CFU) & $\operatorname{Ln}\left(\mathrm{ng}^{-1}\right)$ & \\
\hline Fungi and oomycetes Diversity (H-fungi) & - & \\
\hline Fungi and oomycetes Richness (S-fungi) & - & \\
\hline
\end{tabular}

\subsection{Soil Fertility Attributes}

At each stage, soil samples were collected at $30 \mathrm{~cm}$ depth in each plot (for a total of 18 samples per block; Figure S1). In order to evaluate mineral nitrogen and inorganic phosphorus availability to plants, three soil sub-samples were taken, using an auger at 0-30 $\mathrm{cm}$ depth, and mixed to form a composite sample for each plot. Soil mineral $\mathrm{N}\left(\mathrm{NO}_{3}{ }^{-}-\mathrm{N}+\mathrm{NH}_{4}{ }^{+}-\mathrm{N}\right)$ was extracted by $2 \mathrm{M} \mathrm{KCl}(1: 10 \mathrm{w} / \mathrm{v})$ and measured by continual flow colorimetry according to Krom [25] and Henriksen and Selmer-Olsen [26] for $\mathrm{NH}_{4}{ }^{+}-\mathrm{N}$ and $\mathrm{NO}_{3}{ }^{-}-\mathrm{N}$, respectively. Available $\mathrm{P}(\operatorname{avP})$ was extracted and measured according to the Olsen method [27]. Soil samples from February 2014, November 2014, and October 2015 were air dried, crushed, sieved at $2 \mathrm{~mm}$, and stored until the determination of total organic carbon (TOC) and total N (TN). Total N was analyzed by the Dumas method using the elemental analyzer LECO FP 528, whereas the TOC was analyzed by means of elemental analyzer LECO (RC-612; St. Joseph, MI, USA) using a dry combustion method [28]. 


\subsection{Fungal and Oomycetal Diversity Assessment}

At each of the five sampling stages, two soil samples of $400 \mathrm{~g}$ each were collected in opposite positions at a distance of $40 \mathrm{~cm}$ from each citrus plant and at $0-40 \mathrm{~cm}$ depth, and placed in a plastic bag. The two sub-samples were subsequently mixed in order to generate a single homogeneous and representative sample for each plant's rhizosphere. The rhizospheres of eight plants were considered for each intersection plot, for a total of 48 citrus plants. Soil samples were then air-dried, crushed, passed through at $2 \mathrm{~mm}$ sieve, and stored until subsequent analysis. To isolate soil-borne fungi and oomycetes, serial decimal dilutions of soil samples were carried out [29]. Ten grams of soil were used for serial dilutions. Water Agar (WA), containing $200 \mathrm{mg} \mathrm{mL}^{-1}$ of streptomycin sulphate for preventing bacterial growth, was prepared to isolate fungi and oomycetes. Petri dishes, in triplicates of each dilution, were incubated at $25^{\circ} \mathrm{C}$ for $4-5$ days. After incubation, distinct colonies were counted and values were expressed as colony forming units per gram of soil (CFU/g) and transformed in Ln-(CFU). Colonies were sub-cultured separately on Potato Dextrose Agar (PDA) containing $200 \mathrm{mg} \mathrm{mL}^{-1}$ of streptomycin sulphate for identification at the genus level based on macroscopic and microscopic characteristics. The frequencies of each fungal and oomycetes genus were calculated in percentages as follows: Number of colonies of the genus appeared $\times 100 /$ total number of all colonies isolated from each sample. The Shannon-Weaver [30] index was used to measure the community diversity for each different factor under investigation. The Shannon-Weaver index was calculated as:

$$
\underset{i=1}{S}=-\sum(\mathrm{Pi} \times \ln \mathrm{Pi})
$$

where " $\mathrm{Pi}$ " is the proportion of a given genus relative to the total number of genera found in the $\mathrm{i}$-th sample. "ln Pi" is the natural logarithm of pi. " $\mathrm{S}$ " is the number of genera found in the $\mathrm{i}$-th sample.

\subsection{Weed Diversity Assessment}

At each of the five sampling stages, the weed density and cover-total and at species level-were recorded by placing ten randomly selected $0.25 \times 0.25 \mathrm{~m}^{2}$ squares within each intersection plot in the row and inter-row spaces for density determination, and selecting three $6.0 \times 4.0 \mathrm{~m}^{2}$ areas for cover assessment, obtaining a representative sample per plot. The weed cover abundance/dominance index was estimated according to the Braun-Blanquet scale, as modified by Pignatti [31]. Each Braun-Blanquet class was converted to its midpoint cover value according to Wikum and Shanholtzer [32]. The weed biodiversity was evaluated by calculating diversity indices, namely species Richness ( $R$ ) and Eveness (e) [33] based on the Pielou index:

\section{$\mathrm{H} / \mathrm{Hmax}$}

where $\mathrm{H}$ is the Shannon-Weaver index (as reported in 2.4) and Hmax is the base-e logarithm of R.

\subsection{Statistical Analysis}

A Principal Component Analysis (PCA) was used to determine which combination of variables explained the highest variability in the experimental trial [34], identifying (i) latent patterns and (ii) redundancy among variables $[35,36]$. On the complete list of variables, a parametric one-way Analysis of Variance (ANOVA) was used to verify separately the effects of the Year, System management, and Fertilizer within the PCA scores, in order to assess their contribution to the explained variability. Statistical analysis was carried out using Statistical Package for Social Science (SPSS) 16.0 and PAST (3x. Oslo, Norway) packages. 


\section{Results and Discussion}

\subsection{Principal Component Analysis}

A multivariate analysis of the soil chemical variables, weed species, biodiversity indices, fungi and oomycetes diversity, and biodiversity indices put in evidence interesting correlations among different variables. Results showed a reciprocal effect between plant community and soil-born fungi presence and diversity. Together, weed and fungal diversity was in turn correlated with changes in soil fertility variables.

PCA loadings for the selected components are reported in Table 2. Principal Component 1 (PC1) explains $10.0 \%$ of the total variance in the data matrix. Results put in evidence the positive correlation of selected weed species (Capsella bursa-pastoris (L.) Medik. (CAPBP), Diplotaxis erucoides (L.) DC. (DIPER), Fumaria officinalis L. (FUMOF), Lamium amplixaule L. (LAMAM), Stellaria media (L.) Vill. (STEME), and Urtica urens L. (URTUR)) and a negative correlation between the above set of variables and both Cyperus rotondus L. (CYPRO) and TOC (Figure 2). This result is in accordance with the dominance of the CYPRO species, together with Portulaca oleracea L. (POROL) and Amaranthus retroflexus L. (AMARE), recorded in the two years. Moreover, the densities of the most relevant species put in evidence the dominance of CYPRO in summer and autumn (Figure 3a). In this regard, such results indirectly support the statement that purple nutsedge is one of the most aggressive weeds worldwide, due to its perennial behavior and the continuous reproductive cycle [37].

Table 2. Principal component analysis (PCA) loadings of the soil fertility parameters, weed species, biodiversity indices, and fungi and oomycetes diversity on the first six axes, capturing $37.2 \%$ of the total variance (PC1, 10.0\%; PC2, 6.6\%; PC3, 5.5\%; PC4, 5.2\%; PC5, 5.1\%; PC6, 4.8\%). Loadings are scaled by their respective eigenvalues and represent the correlation of each variable with the PCA axes. Correlation values significant for $p \leq 0.05$ are in bold.

\begin{tabular}{|c|c|c|c|c|c|c|}
\hline & PC1 & PC2 & PC3 & PC4 & PC5 & PC6 \\
\hline $\mathrm{TN}$ & -0.33 & 0.42 & 0.35 & 0.13 & -0.43 & -0.14 \\
\hline TOC & -0.42 & 0.38 & 0.34 & 0.15 & -0.53 & -0.01 \\
\hline $\mathrm{N}-\mathrm{NO}_{3}{ }^{-}$ & 0.09 & -0.35 & 0.08 & -0.07 & 0.50 & 0.12 \\
\hline AMARE & -0.37 & -0.36 & 0.38 & 0.34 & 0.40 & -0.17 \\
\hline BRSNI & -0.29 & -0.18 & 0.02 & 0.02 & -0.47 & 0.07 \\
\hline CAPBP & 0.57 & -0.18 & 0.04 & -0.04 & -0.10 & 0.04 \\
\hline CYPRO & -0.51 & -0.31 & -0.14 & -0.11 & 0.05 & -0.09 \\
\hline DIPER & 0.42 & 0.05 & -0.08 & 0.32 & -0.18 & -0.11 \\
\hline FUMOF & 0.70 & -0.09 & 0.05 & -0.04 & -0.09 & 0.04 \\
\hline LAMAM & 0.53 & -0.03 & -0.19 & 0.40 & -0.17 & -0.16 \\
\hline MALSI & -0.23 & 0.01 & -0.06 & -0.09 & -0.42 & 0.11 \\
\hline POROL & -0.28 & -0.38 & 0.43 & 0.37 & 0.31 & -0.14 \\
\hline Sonchus spp. & 0.37 & -0.03 & 0.49 & -0.23 & -0.01 & 0.33 \\
\hline STEME & 0.61 & 0.13 & 0.11 & -0.11 & -0.10 & 0.06 \\
\hline URTUR & 0.42 & 0.19 & -0.10 & 0.04 & -0.14 & -0.18 \\
\hline Weed density & -0.02 & -0.53 & -0.10 & 0.04 & -0.04 & -0.08 \\
\hline Weed evenness & 0.37 & -0.40 & 0.30 & 0.07 & 0.03 & 0.03 \\
\hline Weed R & 0.36 & 0.40 & 0.14 & 0.12 & 0.27 & 0.11 \\
\hline Fusarium spp. & 0.39 & -0.10 & 0.19 & 0.17 & -0.03 & -0.55 \\
\hline Cladosporium spp. & -0.07 & 0.07 & -0.20 & -0.02 & 0.07 & 0.51 \\
\hline Rhizopus nigricans & 0.23 & 0.05 & 0.11 & 0.23 & -0.04 & 0.45 \\
\hline Ln (CFU) & 0.07 & 0.60 & 0.18 & 0.23 & 0.35 & -0.34 \\
\hline H-fungi & -0.11 & -0.01 & -0.48 & 0.61 & 0.04 & 0.23 \\
\hline S-fungi & -0.05 & -0.07 & -0.43 & 0.62 & -0.01 & 0.14 \\
\hline
\end{tabular}




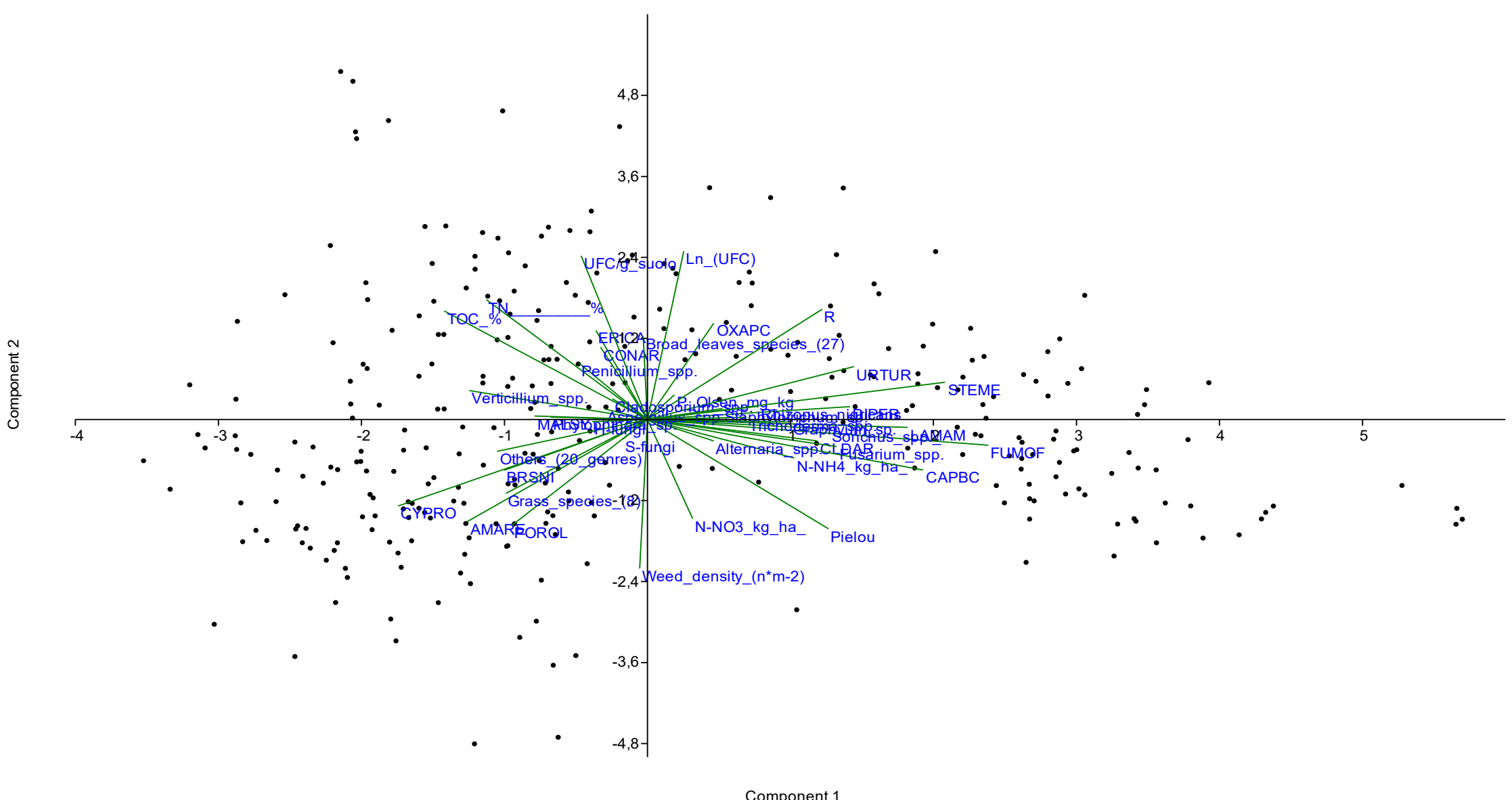

Figure 2. Principal Component Analysis (PCA) ordination diagram (biplot) depicting the localization of the studied samples from the experimental trial over the two years of the experiment in relation to the soil fertility parameters, weed species percentage, weed biodiversity indices and fungi and oomycetes genera percentage and biodiversity indices. The first axis accounts for 10.0\% of the total variation of the dataset. Together, the first two axes explain $16.6 \%$ of the variability in the dataset. The direction and length of the arrows indicate the direction and magnitude in which each variable contributes to the configuration of the point, respectively. The angle between each arrow and the axes is inversely proportional to the correlation between each variable and the axes constructed in the ordination. 


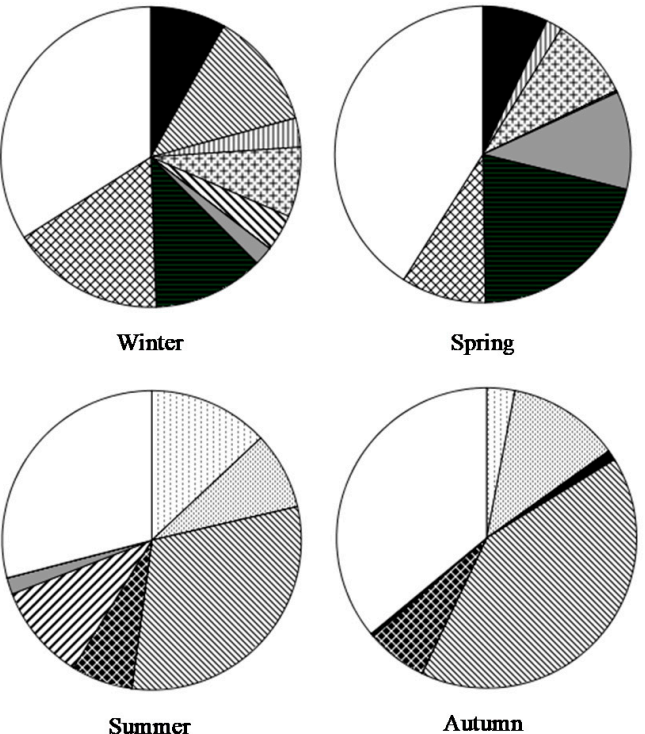

(a)
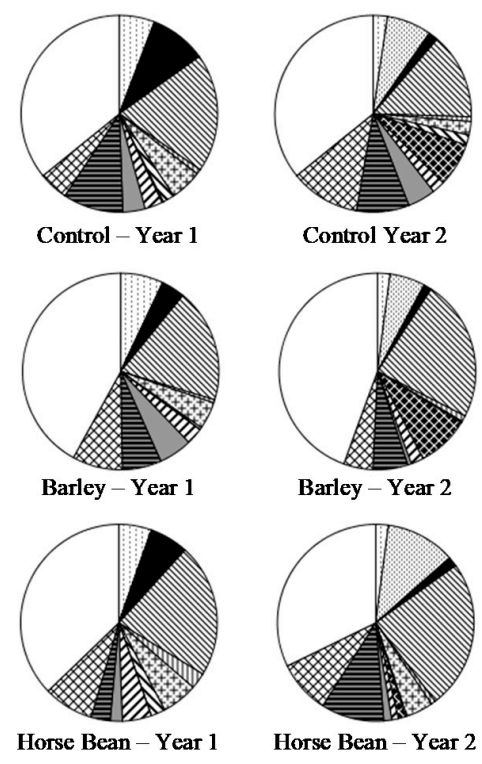

AMARE BRSNI Control Year 2 CAPBP $\mathbb{N}$ CYPRO
WIDIPER 因FUMOF SLAMAM MALSI ZPOROL $\square$ Sonchus spp. ESTEME XURTUR $\square$ Others \%

Figure 3. Weed species relative density in each season over the two-year experiment (a) and in each treatment for each year (b). AMARE: Amaranthus retroflexus L.; BRSNI: Brassica nigra (L.) Koch, CAPBP: Capsella borsa-pastoris (L.) Medik., CYPRO: Cyperus rotondus L.; DIPER: Diplotaxis erucoides (L.) DC.; FUMOF: Fumaria officinalis L.; LAMAM: Lamium amplexicaule L.; MALSI: Malva sylvestris L.; POROL: Portulaca oleracea L.; Sonchus spp.: S. arvensis L., S. asper (L.) Hill, S. oleraceus L.; STEME: Stellaria media (L.) Vill., URTUR: Urtica urens L.

Principal Component 2 (PC2) explains $6.6 \%$ of the total matrix variance. Empirical results outline a negative correlation with weed species density and weed e, and a positive one with weed R, TN and colony-forming units (Ln-(CFU)). This means that where the soil TN was higher, the higher the active fungal component presence, in accordance with [38-40]. Together, where soil TN was higher, the higher the weed $\mathrm{R}$ and the lower the weed e and total density, indicating consolidation of a weed community with few dominant species. This finding was also confirmed by other authors who observed a linear correlation between plant and fungi diversities, revealing a positive response of fungi activity and diversity to changes in plant communities [41-44].

Principal Component 3 (PC3) explains 5.5\% of the total matrix variance, and it evidences a positive correlation with common purslane (POROL) and the sow-thistle group (Sonchus asper (L.) Hill., Sonchus arvensis L., and Sonchus oleraceus L.) and a negative one with fungi and oomycetes diversity indices (H-fungi and S-fungi). This means that the weed community characterized by these weed species had low diversity of fungi in soil. Gonnella et al. [45] report the anti-fungal activity of common purslane extract, due to antioxidant compounds produced by this plant (catalase, ascorbate peroxidise, and glutathione reductase). Our finding suggests the hypothesis that the fungicidal activity of common purslane could have acted by selecting fewer fungi genera than the control.

Principal Component 4 (PC4) explains 5.2\% of the total matrix variance. Results outline a positive correlation among the presence of henbit (LAMAM) and fungi and oomycetes R and diversity. Principal Component 5 (PC5) explains 5.1\% of the total matrix variance. Results show a negative correlation with TN and TOC and a positive correlation with soil nitrate, putting in evidence the possible effect of $\mathrm{N}$ immobilization phenomena due to the addition of organic $\mathrm{C}$ to the soil [46]. Moreover, results outline a positive relationship with redroot pigweed (AMARE) and a negative one with high mallow (MALSI) and black mustard (BRSNI). The positive correlation between soil nitrate and AMARE can be due to the nitrophilous behavior of this species [47], one of the most common weeds in Sicilian citrus orchards [48]. The addition of residues with high C:N ratios can contribute to control this species [49]. As a matter of fact, $\mathrm{C}: \mathrm{N}$ ratios up to 25:1 can lead to net $\mathrm{N}$ mineralization, whereas higher values can determine $\mathrm{N}$ immobilization, with potential selection of weed communities with reduced affinity to 
soil nutrient condition [47]. Not by chance, the C:N ratio is considered as a quality parameter for mulches obtained by ASC management [50].

Principal Component 6 (PC6) explains $4.8 \%$ of the total matrix variance and shows significant interaction with soil-borne fungi and oomycetes parameters. In particular, the Fusarium genus showed a negative correlation with Cladosporium genus and Rhizopus nigricans presence, highlighting the presence of different fungal communities in the experiment.

\subsection{Differences among Compared Systems}

A three-way ANOVA was implemented to verify the effect of the Year (Y), S (Cont, B, and HB) and F (Min and Comp) within the results of the PCA (component scores), in order to identify their contribution to the explained variability (Table 3). Results showed no significant three-way interaction among the factors, whereas 'Year $\times$ System' $(Y \times S)$ was significant for PC1, PC2, PC3, and PC5 (Table 4). Non-significant $\mathrm{Y} \times \mathrm{F}$ and $\mathrm{S} \times \mathrm{F}$ interactions were recorded.

Table 3. Component score means for the compared treatments.

\begin{tabular}{|c|c|c|c|c|c|c|}
\hline & PC1 & PC2 & PC3 & PC4 & PC5 & PC6 \\
\hline \multicolumn{7}{|l|}{ Year $(Y)$} \\
\hline Y 1 & $0.90 \mathrm{a}^{2}$ & $0.32 \mathrm{~b}$ & 0.10 & 0.10 & 0.05 & -0.00 \\
\hline Y 2 & $-0.63 \mathrm{~b}$ & $-0.22 \mathrm{a}$ & -0.07 & -0.07 & -0.03 & 0.00 \\
\hline sig. ${ }^{1}$ & $* * *$ & $* * *$ & n.s. & n.s. & n.s. & n.s. \\
\hline \multicolumn{7}{|l|}{ System (S) } \\
\hline Cont & $1.03 \mathrm{a}$ & $-1.11 \mathrm{c}$ & $0.23 \mathrm{a}$ & 0.24 & $0.43 \mathrm{a}$ & $0.04 \mathrm{ab}$ \\
\hline Barley (B) & $0.07 \mathrm{~b}$ & $1.14 \mathrm{a}$ & $-0.57 \mathrm{~b}$ & -0.14 & $0.53 \mathrm{a}$ & $-0.32 \mathrm{~b}$ \\
\hline Horse Bean (HB) & $-1.09 \mathrm{c}$ & $-0.05 b$ & $0.36 \mathrm{a}$ & -0.10 & $-0.91 \mathrm{~b}$ & $0.28 \mathrm{a}$ \\
\hline sig. & $* * *$ & $* * *$ & $* * *$ & n.s. & $* * *$ & $* *$ \\
\hline \multicolumn{7}{|l|}{ Fertilizer (F) } \\
\hline Min & 11.3 & $-0.14 \mathrm{~b}$ & $0.21 \mathrm{a}$ & -0.06 & 0.05 & 0.14 \\
\hline Comp & -11.3 & $0.14 \mathrm{a}$ & $-0.21 \mathrm{a}$ & 0.06 & -0.05 & -0.14 \\
\hline sig. & n.s. & $* * *$ & $* * *$ & n.s. & n.s. & n.s. \\
\hline$Y \times S$ & $* * *$ & $* *$ & $* * *$ & n.s. & $* * *$ & n.s. \\
\hline $\mathrm{Y} \times \mathrm{F}$ & n.s. & n.s. & n.s. & n.s. & n.s. & n.s. \\
\hline $\mathrm{S} \times \mathrm{F}$ & n.s. & n.s. & n.s. & n.s. & n.s. & n.s. \\
\hline $\mathrm{Y} \times \mathrm{S} \times \mathrm{F}$ & n.s. & n.s. & n.s. & n.s. & n.s. & n.s. \\
\hline
\end{tabular}

Table 4. Component score means. Effect of System management $x$ Fertilizer and Year $(\mathrm{Y}) \times$ System management (Cont; Barley, B; Horse bean, HB) interactions.

\begin{tabular}{ccccc}
\hline & PC1 & PC2 & PC3 & PC5 \\
\hline Y 1 Cont & $3.22 \mathrm{a}^{2}$ & $-0.77 \mathrm{~b}$ & $-0.38 \mathrm{c}$ & $-0.31 \mathrm{c}$ \\
Y 2 Cont & $-0.52 \mathrm{c}$ & $-1.36 \mathrm{c}$ & $0.65 \mathrm{~b}$ & $1.17 \mathrm{a}$ \\
Y 1 B & $0.54 \mathrm{~b}$ & $1.07 \mathrm{a}$ & $-0.61 \mathrm{c}$ & $0.82 \mathrm{a}$ \\
Y 2 B & $-0.62 \mathrm{c}$ & $1.19 \mathrm{a}$ & $-0.55 \mathrm{c}$ & $0.24 \mathrm{~b}$ \\
Y 1 HB & $0.89 \mathrm{~b}$ & $0.65 \mathrm{a}$ & $1.27 \mathrm{a}$ & $-0.37 \mathrm{c}$ \\
Y 2 HB & $-1.92 \mathrm{~d}$ & $-0.53 \mathrm{~b}$ & $-0.29 \mathrm{c}$ & $-1.45 \mathrm{~d}$ \\
Sig. & $* * *$ & $* * * *$ & $* *$
\end{tabular}

1 n.s. $=$ not significant; ${ }^{* * *}=p \leq 0.001 ;{ }^{* *}=p \leq 0.01 ;{ }^{*}=p \leq 0.05 .{ }^{2}$ Mean values in each column followed by a different letter are significantly different according to the Tuckey test.

Results for $\mathrm{Y} \times \mathrm{S}$ outlined the strong effect of $\mathrm{Y}$ on the studied variables (Table 4 ). These differences can be explained by weather-related differences between the two study years (Figure 1). In particular, $Y 1$ was characterized by lower rainfall than $Y 2$ and the long-term average $(339 \mathrm{~mm}$ vs $660 \mathrm{~mm}$ and $547 \mathrm{~mm}$, respectively).

The three systems showed a positive correlation with PC1 in the first year and a negative one in the second, possibly indicating a different response to local weather conditions. The Cont showed the 
highest value of the component score mean in $Y 1$, while the $\mathrm{HB}$ showed the lowest one in $\mathrm{Y} 2$, whereas no differences between $\mathrm{B}$ and $\mathrm{HB}$ were recorded in the first year (both positively correlated with $\mathrm{Y} 1$ Cont) and between Cont and B in the second year (both negatively correlated with Y 1 Cont). Results provided evidence that there were different weed communities between the two years. In particular, in the second year, weed community was strictly associated with the presence of purple nutsedge (CYPRO) (Figure 3b) and with higher TOC than the first year. Barley treatment showed the highest positive correlation with $\mathrm{PC} 2$, together with $\mathrm{HB}$ in the second year, outlining a reduction of weed density and evenness compared to the Cont. HB showed higher correlation with TN and CFU (Table 2), indicating a latent impact on microbial activity, which could be investigated more extensively in further studies. Barley treatment did not show differences with respect to $\mathrm{Y}$ also for PC3, highlighting the lowest negative correlation in both years with Cont in $Y 1$ and HB in $Y 2$. The highest value of the component score mean was recorded for $\mathrm{HB}$ in the first year. These results put in evidence how $\mathrm{B}$ resulted in a reduction of common purslane and sow-thistles and, together, the highest fungal diversity. Horse bean showed a negative correlation with PC5 in both the years, recording the significantly lower score mean in $\mathrm{Y} 2$. It showed higher TOC and TN than other treatments and the lower soil nitrate level, corresponding with a weed community composition shift with reduction of AMARE and increase of BRSNI and MALSI compared to B and Cont. On the other hand, B showed a positive correlation with PC5 in both the years, whereas a negative relationship was recorded for HB. This evidence outlines a different composition of fungal community due to ASC presence, as far as its stability despite changing in condition compared to the Cont (Figure 1).

The $\mathrm{F}$ factor showed significant differences between the two used materials for PC2 and PC3. The use of compost showed higher contribution to TN increase as far as the UFC of soil-born fungi and oomycetes, together with fungal diversity parameters (positive correlation with PC2 and negative with PC3). On the other hand, the use of mineral fertilizer seemed to determine more uniform weed communities, with lower species richness and higher density than using compost, characterized by common purslane and sow-thistles (Table 2).

Few significant differences for the three systems emerged from comparing the performance during and after the ASC cycle, but none showed changes from positive to negative correlation, or vice versa, between the two phases (data not reported).

Overall, the results showed differences among the three compared systems. The systems with ASC showed changes in weed community composition compared to the Cont, with the lowest weed density associated to B and the highest to the Cont (PC1, PC2, and PC3), in accordance with several studies corroborating the ASC contribution—grass species in particular-in managing weeds $[17,18,50]$. Moreover, B showed also the highest fungal and oomycetes diversity, with some changes in the community of soil-borne fungi compared to HB (PC2, PC3, and PC6). This result is in accordance with previous studies, highlighting a link between ASC introduction and microbial communities [51,52]. On the other hand, HB showed the highest effect on soil fertility parameters, being characterized by organic matter parameters (TOC and TN) and a modified pattern in soil mineral $\mathrm{N}$ availability (PC2 and PC5). As far as the fertilizer factor was concerned, results put in evidence how the use of compost could promote the system biodiversity richness (weed and fungi R, H-fungi, CFU) and a reduction in weed density, probably due to $\mathrm{N}$ immobilization phenomena in accordance with previous findings [53].

\section{Conclusions}

Human activity strongly influences agroecosystem structure and functioning. Anthropogenic drivers, such as land management or climate change, have a combined effect on the agroecosystem components and processes. Understanding these linkages can be an evaluable way to predict the effect of a single agronomic practice, at the farm and territorial scales. Even if two years are not enough to draw general conclusions, the results of this study indicate that the agroecological approach, and in particular the introduction of ASCs, could alter the mutual relationships among the components of the 
agroecosystem. Changes in plant community composition, driven by ASC and organic amendment, seem to affect the below-ground community and vice versa, resulting in changes in soil nutrient and organic matter conservation and management.

By acting on planned biodiversity, the ASC introduction showed a higher impact on system components than the substitution of mineral fertilizer with on-farm compost. In general, results highlighted the role of the agroecological practices towards agrobiodiversity conservation and enhancement, and the link among the different components of the agroecosystem. Further researches should be addressed to better analyze the effect of management strategies on agrobiodiversity and the relationship between agrobiodiversity and the related ecosystem services.

Supplementary Materials: The following are available online at http:/ /www.mdpi.com/2073-4395/9/2/85/s1, Figure S1: Experimental layout of the PALAP9 long-term experimental trial. The criss-cross design was organized in three blocks (A). In each block (B), the vertical strip was assigned to the System management (S), which foresaw the introduction of agroecological service crop (ASC) species: (i) Barley, Hordeum vulgare L. (B), and (ii) Horse bean, Vicia faba L. var. minor (HB), compared with (iii) control without ASC (Cont). The horizontal strip was assigned to the Fertilizer (F) with the comparison of a commercial fertilizer (Min) and a compost compliant with EU organic regulation. Soil was sampled $50 \mathrm{~cm}$ away from three orange plants in each plot (B).

Author Contributions: Conceptualization, C.C., E.T., and G.R.; methodology, C.C., E.T., A.L.T. and G.R.; formal analysis, C.C. and L.S.; investigation C.C., A.L.T., and G.R.; data curation, E.T., L.S., and V.B.; writing-original draft preparation, C.C.; writing-review and editing, E.T., A.L.T., F.F., and G.R.; visualization, C.C.; supervision, G.R.; project administration, G.R.; funding acquisition, G.R.

Funding: This paper is a result of the ITACA (Technical and scientific addresses to the plant and the conversion of orchards to organic farming) and BIOPAC (Innovative and sustainable management of organic orchards) research projects funded by the Organic Farming Office of the Italian Ministry of Agriculture in the frame of the National Action Plan for Organic food and farming.

Acknowledgments: The authors wish to thank Biagio Torrisi, Maria Allegra, and Stefano Trotta for their contribution to the process of field operation, soil and plant sampling, and analyses.

Conflicts of Interest: The authors declare no conflict of interest. The funders had no role in the design of the study; in the collection, analyses, or interpretation of data; in the writing of the manuscript; or in the decision to publish the results.

\section{References}

1. Alexandratos, N.; Bruinsma, J. World Agriculture towards 2030/2050: The 2012 Revision; ESA Working Paper No. 12-03; FAO: Rome, Italy, 2012.

2. IFOAM. Principles of Organic Agriculture; IFOAM Head Officer: Bonn, Germany, 2005.

3. Rahmann, G.; Reza Ardakani, M.; Bàrberi, P.; Boehm, H.; Canali, S.; Chander, M.; David, W.; Dengel, L.; Erisman, J.W.; Galvis-Martinez, A.C.; et al. Organic Agriculture 3.0 is innovation with research. Org. Agric. 2017, 7, 169-197. [CrossRef]

4. Darnhofer, I.; Lindenthal, T.; Bartel-Kratochvil, R.; Zollitsch, W. Conventionalisation of organic farming practices: From structural criteria towards an assessment based on organic principles. Agron. Sustain. Dev. 2010, 30, 67-81. [CrossRef]

5. Niggli, U. Incorporating Agroecology into Organic Research-An Ongoing Challenge. Sustain. Agric. Res. 2015, 4, 149-157. [CrossRef]

6. Francis, C.; Lieblein, G.; Gliessman, S.; Breland, T.A.; Creamer, N.; Harwood, R.; Salomonsson, L.; Helenius, J.; Rickerl, D.; Salvador, R.; et al. Agroecology: The ecology of food systems. J. Sustain. Agric. 2003, 22, 99-118. [CrossRef]

7. Gliessman, S. Transforming food systems with agroecology. Agroecol. Sustain. Food Syst. 2016, 40, 187-189. [CrossRef]

8. Magdoff, F. Ecological agriculture: Principles, practices, and constraints. Renew. Agric. Food Syst. 2007, 22, 109-117. [CrossRef]

9. Wezel, A.; Casagrande, M.; Celette, F.; Vian, J.F.; Ferrer, A.; Peigné, J. Agroecological practices for sustainable agriculture. A review. Agron. Sustain. Dev. 2014, 34, 1-20. [CrossRef]

10. Wood, S.A.; Karp, D.S.; DeClerck, F.; Kremen, C.; Naeem, S.; Palm, C.A. Functional traits in agriculture: Agrobiodiversity and ecosystem services. Trends Ecol. Evol. 2015, 30, 531-539. [CrossRef] 
11. Love, B.; Spaner, D. Agrobiodiversity: Its Value, Measurement, and Conservation in the Context of Sustainable Agriculture. J. Sustain. Agric. 2007, 31, 53-82. [CrossRef]

12. Tilman, D. The ecological consequences of changes in biodiversity: A search for general principles. Ecology 1999, 80, 1455-1474. [CrossRef]

13. Bommarco, R.; Kleijn, D.; Potts, S.G. Ecological intensification: Harnessing ecosystem services for food security. Trends Ecol. Evol. 2013, 28, 230-238. [CrossRef] [PubMed]

14. Canali, S.; Diacono, M.; Campanelli, G.; Montemurro, F. Organic No-Till with Roller Crimpers: Agro-ecosystem Services and Applications in Organic Mediterranean Vegetable Productions. Sustain. Agric. Res. 2015, 4, 70-79. [CrossRef]

15. Depalo, L.; Burgio, G.; von Fragstein, P.; Kristensen, H.L.; Bavec, M.; Robačer, M.; Campanelli, G.; Canali, S. Impact of living mulch on arthropod fauna: Analysis of pest and beneficial dynamics on organic cauliflower (Brassica oleracea L. var. botrytis) in different European scenarios. Renew. Agric. Food Syst. 2016, 32, $240-247$. [CrossRef]

16. Navarro-Miró, D.; Cabellero-López, B.; Blanco-Moreno, J.M.; Pérez-Ferrer, A.; Depalo, L.; Masetti, A.; Burgio, G.; Canali, S.; Sans, F.X. Agro-ecological Service Crops with roller crimper termination enhance ground-dwelling predator communities and pest regulation. In Proceedings of the Innovative Research for Organic 3.0 Science track at the Organic Word Congress, Delhi, India, 9-11 November 2017; Volume 1, pp. 416-419.

17. Ciaccia, C.; Kristensen, H.L.; Campanelli, G.; Xie, Y.; Testani, E.; Leteo, F.; Canali, S. Living mulch for weed management in organic vegetable cropping systems under Mediterranean and North European conditions. Renew. Agric. Food Syst. 2016, 32, 248-262. [CrossRef]

18. Ciaccia, C.; Canali, S.; Campanelli, G.; Testani, E.; Montemurro, F.; Leteo, F.; Delate, K. Effect of roller-crimper technology on weed management in organic zucchini production in a Mediterranean climate zone. Renew. Agric. Food Syst. 2016, 31, 111-121. [CrossRef]

19. Trinchera, A.; Testani, E.; Ciaccia, C.; Campanelli, G.; Leteo, F.; Canali, S. Effects induced by living mulch on rhizosphere interactions in organic artichoke: The cultivar's adaptive strategy. Renew. Agric. Food Syst. 2016, 32, 214-223. [CrossRef]

20. Yue, X.; Kristensen, H.L. Overwintering grass-clover as intercrop and moderately reduced nitrogen fertilization maintain yield and reduce the risk of nitrate leaching in an organic cauliflower (Brassica oleracea L. var. botrytis) agroecosystem. Sci. Hort. 2016, 206, 71-79.

21. Callaway, R.M.; Mahall, B.E.; Wicks, C.; Pankey, J.; Zabinski, C. Soil fungi and the effects of an invasive forb on grasses: Neighbor identity matters. Ecology 2003, 84, 129-135. [CrossRef]

22. IUSS Working Group. WRB World Reference Base for Soil Resources 2014, Update 2015 International Soil Classification System for Naming Soils and Creating Legends for Soil Maps; World Soil Resources Reports No. 106; FAO: Rome, Italy, 2015.

23. Peel, M.C.; Finlayson, B.L.; McMahon, T.A. Updated world map of the Köppen-Geiger climate classification. Hydrol. Earth Syst. Sci. 2007, 11, 1633-1644. [CrossRef]

24. Canali, S.; Trinchera, A.; Intrigliolo, F.; Pompili, L.; Nisini, L.; Mocali, S.; Torrisi, B. Effect of long term addition of composts and poultry manure on soil quality of citrus orchards in Southern Italy. Biol. Fertil. Soils 2004, 40, 206-210. [CrossRef]

25. Krom, M.D. Spectrophotometric determination of ammonia: A study of a modified Berthelot reaction using salicylate and dichloroisocyanurate. Analyst 1980, 105, 305-316. [CrossRef]

26. Henriksen, A.; Selmer-Olsen, A.R. Automatic methods for determining nitrate and nitrite in water and soil extracts. Analyst 1970, 95, 514-518. [CrossRef]

27. Olsen, S.R.; Sommers, L.E. Phosphorus. In Methods of Soil Analysis; Page, A.L., Ed.; American Society of Agronomy, Soil Science Society of America: Madison, WI, USA, 1982; Part 2; pp. 403-430.

28. LECO Corporation. Instruction Manual-CHN-600 Elemental Analyzer for Macro-Samples System; LECO Corporation: St. Joseph, MI, USA, 1987; p. 49085.

29. Waksman, S.A. A method for counting the number of fungi in the soil. J. Bacteriol. 1922, 7, 339-341. [PubMed]

30. Shannon, C.E.; Weaver, W. The Mathematical Theory of Communicatio; University of Illinois Press: Urbana, IL, USA, 1948.

31. Pignatti, S. Geobotanica. In Trattato di Botanica; Cappelletti, C., Ed.; UTET: Turin, Italy, 1976; pp. 801-997. 
32. Wikum, D.A.; Shanholtzer, G. Application of the Braun-Blanquet cover-abundance scale for vegetation analysis in land development studies. Environ. Manag. 1978, 2, 323-329. [CrossRef]

33. Magurran, A.E. Ecological Diversity and Its Measurement; Springer Science \& Business Media: Dordrecht, The Netherlands, 2013.

34. Gotelli, N.J.; Ellison, A.M. A Primer of Ecological Statistics, 2nd ed.; Sinauer Associates Inc.: Sunderland, MA, USA, 2004.

35. Pili, S.; Grigoriadis, E.; Carlucci, M.; Clemente, M.; Salvati, L. Towards Sustainable Growth? A Multi-criteria Assessment of (Changing) Urban Forms. Ecol. Indic. 2017, 76, 71-80. [CrossRef]

36. Duvernoy, I.; Zambon, I.; Sateriano, A.; Salvati, L. Pictures from the Other Side of the Fringe: Urban Growth and Peri-urban Agriculture in a Post-industrial City (Toulouse, France). J. Rural Stud. 2018, 57, 25-35. [CrossRef]

37. Bangarwa, S.K.; Norsworthy, J.K.; Jha, P.; Malik, M. Purple Nutsedge (Cyperus rotundus) Management in an Organic Production System. Weed Sci. 2008, 56, 606-613. [CrossRef]

38. Joshi, I.J.; Chauhan, R.K.S. Soil fungal ecology of cultivated areas of Chambal ravines. Proc. Indian Natl. Sci. Acad. 1981, 47, 248-254.

39. Hart, S.C.; Stark, J.M. Nitrogen limitation of the microbial biomass in an old-growth forest soil. EcoScience 1997, 4, 91-98. [CrossRef]

40. Zhang, Q.H.; Zak, J.C. Effects of water and nitrogen amendment on soil microbial biomass and fine root production in a semi-arid environment in west Texas. Soil Biol. Biochem. 1998, 30, 39-45. [CrossRef]

41. Ladygina, N.; Hedlund, K. Plant species influence microbial diversity and carbon allocation in the rhizosphere. Soil Biol. Biochem. 2010, 42, 162-168. [CrossRef]

42. Rottstock, T.; Joshi, J.; Kummer, V.; Fischer, M. Higher plant diversity promotes higher diversity of fungal pathogens, while it decreases pathogen infection per plant. Ecology 2014, 95, 1907-1917. [CrossRef] [PubMed]

43. LeBlanc, N.; Kinkel, L.; Kistler, H.C. Soil fungal communities respond to grassland plant community richness and soil edaphics. Microb. Ecol. 2015, 70, 188-195. [CrossRef] [PubMed]

44. Frąc, M.; Hannula, S.E.; Bełka, M.; Jędryczka, M. Fungal biodiversity and their role in soil health. Front. Microbiol. 2018, 9, 707. [CrossRef] [PubMed]

45. Gonnella, M.; Charfeddine, M.; Conversa, G.; Santamaria, P. Purslane: A review of its potential for health and agricultural aspects. Eur. J. Plant Sci. Biotechnol. 2010, 4, 131-136.

46. Abbasi, M.K.; Tahir, M.M.; Sabir, N.; Khurshid, M. Impact of the addition of different plant residues on nitrogen mineralization-immobilization turnover and carbon content of a soil incubated under laboratory conditions. Solid Earth 2015, 6, 197-205. [CrossRef]

47. Pignatti, S. Valori di bioindicazione delle piante vascolari della flora d'Italia. BraunBlanquetia 2005, 39, 2-97.

48. Brullo, S.; Giusso Del Galdo, G.; Guarino, R.; Minissale, P. A survey of the weedy communities of Sicily. Annali di Botanica 2007, 7, 127-161. [CrossRef]

49. Halde, C.; Entz, M.H. Plant species and mulch application rate affected decomposition of cover crop mulches used in organic rotational no-till systems. Can. J. Plant Sci 2016, 96, 59-71. [CrossRef]

50. Hill, E.C.; Renner, K.A.; Sprague, C.L.; Davis, A.S. Cover crop impact on weed dynamics in an organic dry bean system. Weed Sci. 2016, 64, 261-275. [CrossRef]

51. Calderon, F.J.; Nielsen, D.; Acosta-Martinez, V.; Vigil, M.F.; Drew, L.Y. Cover crop and irrigation effects on soil microbial communities and enzymes in semiarid agroecosystems of the central Great Plains of North America. Pedosphere 2016, 26, 192-205. [CrossRef]

52. Finney, D.M.; Buyer, J.S.; Kaye, J.P. Living cover crops have immediate impacts on soil microbial community structure and function. J. Soil Water Constr. 2017, 72, 361-373. [CrossRef]

53. Diacono, M.; Montemurro, F. Long-term effects of organic amendments on soil fertility. Sustain. Agric. 2011, 2, 761-786.

(C) 2019 by the authors. Licensee MDPI, Basel, Switzerland. This article is an open access article distributed under the terms and conditions of the Creative Commons Attribution (CC BY) license (http:/ / creativecommons.org/licenses/by/4.0/). 